Article

\title{
Structural Characterization of Octahedral Sheet in Dioctahedral Smectites by Thermal Analysis
}

\author{
Xiaoli Wang ${ }^{1,2}$, Yan $\mathrm{Li}^{1,2}$ and Hejing Wang ${ }^{1,2, *(1)}$ \\ 1 School of Earth and Space Sciences, Peking University, Beijing 100871, China; \\ xiaoli.wang@pku.edu.cn (X.W.); liyan-pku@163.com (Y.L.) \\ 2 Key Laboratory of Orogenic Belt and Crustal Evolution, Ministry of Education, Beijing 100871, China \\ * Correspondence: hjwang@pku.edu.cn; Tel.: +86-010-6275-0764
}

Received: 9 March 2020; Accepted: 10 April 2020; Published: 13 April 2020

\begin{abstract}
The structures of octahedral sheets of dioctahedral phyllosilicates show cis-vacant (cv) and trans-vacant $(t v)$ configurations due to the different distributions of the octahedral cations over cisand trans-sites. On the basis of the different dehydroxylation temperatures, a thermal analysis is an effective method used to identify the $c v$ and $t v$ configurations of an octahedral sheet in dioctahedral smectites. The proportions of $c v$ and $t v$ configurations were determined by fitting the derivative thermogravimetry (DTG) curves. A wide range of $c v$ and $t v$ proportions were detected in the samples. The dehydroxylation temperatures of samples consisting of $c v$ configuration are about 150 to $200{ }^{\circ} \mathrm{C}$ higher than those consisting of $t v$ configurations. The samples were classified as $t v$ varieties when octahedral $\mathrm{Fe}^{3+}>0.46 \mathrm{~mol} / \mathrm{FU}$, and the pure to dioctahedral smectites were found when $\mathrm{Fe}^{3+}>$ $1.8 \mathrm{~mol} / \mathrm{FU}$. A clear linear relationship was found between the content of octahedral $\mathrm{Fe}^{3+}$ and $\mathrm{Al}^{3+}$ and the proportion of $c v$ and $t v$ configurations. The substitution of $\mathrm{Al}^{3+}$ by $\mathrm{Fe}^{3+}$ in the octahedral sheets is the main factor for the formation of $t v$ varieties. There was no relationship detected between the layer charge density, octahedral $\mathrm{Mg}^{2+}$ content, and the proportion of $t v$ and $c v$. The present results indicate that the iron content has a significant effect on the structure of the octahedral sheet.
\end{abstract}

Keywords: cis-vacant; trans-vacant; dioctahedral smectites; dehydroxylation; thermal analysis

\section{Introduction}

Smectites are used widely in industrial and environmental applications due to their physical and chemical properties, for example, cation exchange capacity, swelling behavior, and adsorption capacity [1]. The properties of smectites are closely related to their structural features $[2,3]$.

Smectites are typical 2:1 layers of clay minerals, composed of two tetrahedral silicate sheets $(\mathrm{T})$ and one octahedral sheet $(\mathrm{O})$. In each layer, the octahedral sheet is sandwiched between the two tetrahedral sheets (TOT) (Figure 1). In the tetrahedral sheets, the dominant cation is $\mathrm{Si}^{4+}$, but it can often be substituted by trivalent cation such as $\mathrm{Al}^{3+}$. In the octahedral sheet, the common cations are $\mathrm{Al}^{3+}, \mathrm{Mg}^{2+}, \mathrm{Fe}^{3+}$, or $\mathrm{Fe}^{2+}$, but other cations, such as $\mathrm{Li}^{+}, \mathrm{Ni}^{2+}$, and $\mathrm{Cr}^{3+}$ have also been identified in octahedral sites. Two arrangements exist in the octahedral sheet, if all octahedral sites are filled with bivalent cations such as $\mathrm{Mg}^{2+}$ and $\mathrm{Fe}^{2+}$, the structure is called trioctahedral; if two-thirds of octahedral sites are occupied by trivalent cations such as $\mathrm{Al}^{3+}$ and $\mathrm{Fe}^{3+}$, the structure is known as dioctahedral. The general chemical formula for dioctahedral smectites is:

$$
\left(\mathrm{M}_{x+y}^{+} \cdot n \mathrm{H}_{2} \mathrm{O}\right)\left(\mathrm{R}_{2-y}^{3+} \mathrm{R}_{y}^{2+}\right)\left[\left(\mathrm{Si}_{4-x}^{4+} \mathrm{Al}_{x}^{3+}\right) \mathrm{O}_{10}(\mathrm{OH})_{2}\right]
$$

where $\mathrm{M}^{+}$represents the exchangeable interlayer cations; $\mathrm{R}^{2+}$ and $\mathrm{R}^{3+}$ refer to divalent and trivalent octahedral cations, respectively; $x$ and $y$ indicate the tetrahedral and octahedral layer charge, 
respectively [2]. The most important species of dioctahedral smectites are montmorillonite, beidellite, and nontronite. In general, octahedra shows two different configurations related to the disposition of hydroxyl groups, for example, cis- and trans-octahedron. In the cis-octahedron, the OH groups are on the same side, whereas in the trans-octahedron, the $\mathrm{OH}$ groups are on the opposite side (Figure 2).

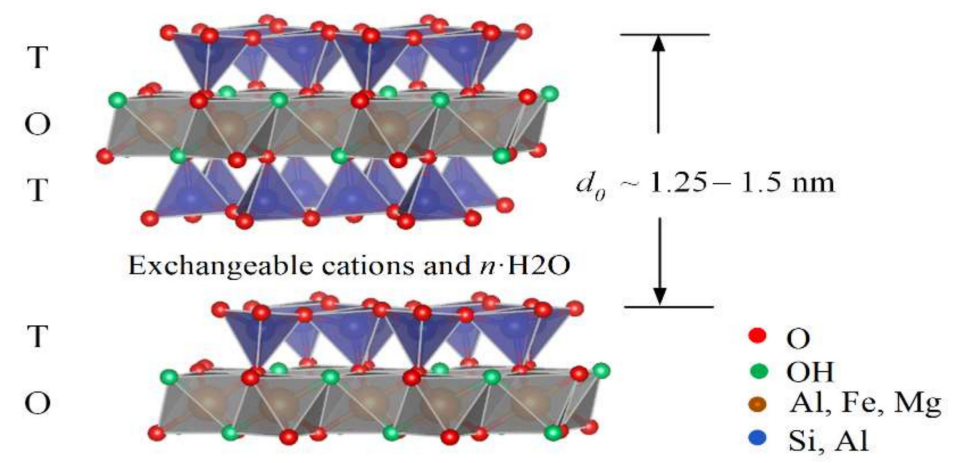

Figure 1. General structure of smectites.

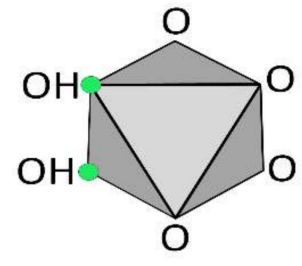

(a)

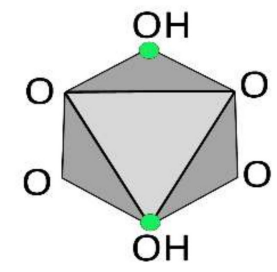

(b)

Figure 2. Structure of (a) cis-octahedron and (b) trans-octahedron.

In dioctahedral smectites, one third of the octahedral positions are vacant. Thus, the octahedral sheet with cis-sites vacant is called the cis-vacant ( $c v)$ configuration (Figure 3a), and with trans-sites vacant it is called the trans-vacant ( $t v$ ) configuration (Figure $3 b$ ). This kind of cations' distribution was first proposed by Méring and Oberlin in 1971 [4]. Then, Tsipursky and Drits [5] found that natural dioctahedral smectites cover a wide range of proportions of $c v$ and $t v$ structures, and normally, montmorillonites are $c v$ and illites are $t v$.

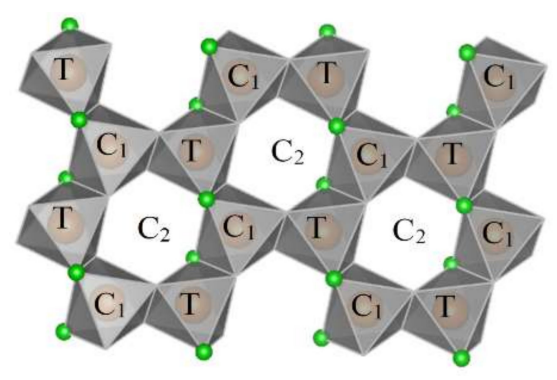

(a)

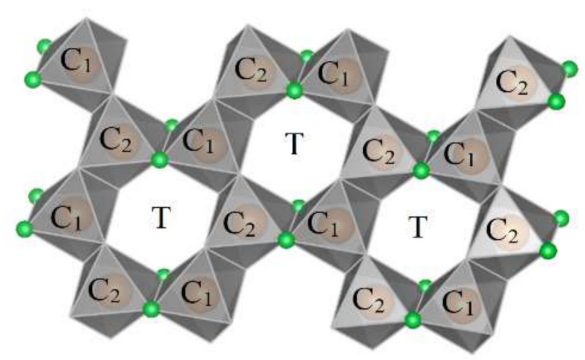

(b)

$$
\begin{aligned}
-\mathrm{OH} & \\
\mathrm{C} 1, \mathrm{C} 2 & \text { cis-octahedron } \\
\mathrm{T} & \text { trans-octahedron }
\end{aligned}
$$

Figure 3. Octahedral sheet of (a) cis-vacant configuration and (b) trans-vacant configuration in dioctahedral smectites.

In general, 2:1 dioctahedral phyllosilicates show structural defects such as a stacking disorder which makes it difficult to obtain precise structural information by the X-ray powder diffraction (XRD) method, especially for the smectite group [6]. Drits et al. [7] found that the dehydroxylation temperature is related to the structure of the octahedral layer. Since then, the structural transformations have been 
extensively studied during dehydroxylation of dioctahedral 2:1 dioctahedral phyllosilicates [8-15]. These studies showed that the chemical composition and the distribution of cations over cis- and trans-sites in the octahedral sheet are two major factors affecting the dehydroxylation of micas, smectites, and illite/smectite (I/S). The dehydroxylation of tv clay minerals occurs in one stage; each two adjacent $\mathrm{OH}$ groups form a water molecule and leave one residual oxygen atom, the octahedral cations become five-coordinated. The dehydroxylation of $c v$ clay minerals occurs in two stages. First, each two adjacent $\mathrm{OH}$ groups are replaced by the residual oxygen atom and the octahedral cations become five- and six-coordinated in cis- and trans-sites, respectively. Secondly, the cations migrate from trans-sites into the former cis-vacant site $[7,10]$. This requires additional thermal energy. Therefore, varieties containing $c v$ configuration have dehydroxylation temperature from 100 to $200{ }^{\circ} \mathrm{C}$ higher than those consisting of $t v$ configuration. The relationships between structural properties and $t v, c v$ structures has been investigated [16-18]. The octahedral iron content is highly related to the tv configuration. The Fe-rich dioctahedral phyllosilicates occur most as a tv configuration, and the Al-rich dioctahedral phyllosilicates prefer to form a $c v$ configuration [16]. Wolters et al. found that the main influence on the $t v$ configuration was due to $\mathrm{Fe}^{3+}$ substitution for $\mathrm{Al}^{3+}$ in the octahedral sheet [17]. Kaufhold et al. confirmed the relationship between iron content and the ratio of $c v$ and $t v$ sites from an energy point of view [18]. The dehydroxylation temperature also depended on the iron content.

The information of octahedral structure reflects the thermal reactions which are important for the industrial applications of smectites, for example, the production of supplementary cementitious materials and geopolymers [19]. In addition, the thermal stability of bentonite determines their amount during the foundry process. Therefore, further research about the relationship between the octahedral structure, including $c v$ and $t v$ varieties, and the physicochemical properties of smectites is necessary in order to gain a better understanding of the formation mechanism of 2:1 dioctahedral phyllosilicates and their industrial application.

The thermal analysis is considered to be an effective method to discriminate the structure of the octahedral sheet. According to Drits et al. $[7,8]$, the tv smectites have a dehydroxylation temperature between 500 to $550{ }^{\circ} \mathrm{C}$, and the $c v$ smectites have a dehydroxylation temperature about $700{ }^{\circ} \mathrm{C}$. The proportion of the peak areas in different temperatures reflects the proportion of cis- and trans-vacant configurations. In this study, the thermogravimetric (TG) analysis was used to characterize the structure of the octahedral sheet. The proportions of $c v$ and $t v$ configurations were calculated by fitting the derivative thermogravimetry (DTG) curves which provided the information of the dehydroxylation reaction, for example, the temperature when water molecules exit the structure from each of the two $\mathrm{OH}$ groups. The purpose of this study is to characterize the $t v$ and $c v$ configurations in dioctahedral smectites by thermogravimetric (TG) analysis and classify samples, to (1) characterize the structure of the octahedral sheet in dioctahedral smectites by thermal analysis and (2) verify the relationships between the proportions of $t v$ and $c v$ and the structural properties, such as cation distribution in the octahedral and tetrahedral sheets and the layer charge density.

\section{Materials and Methods}

\subsection{Sample Preparation and Characterization}

A series of well-investigated dioctahedral smectite samples $[17,20]$ and international reference samples (Source clays, CMS) were used in this study to avoid additional sampling and screening (Table 1). All samples were purified firstly. Only carbonates were found in the bulk samples. The chemical pretreatment to eliminate this impurity was performed according to Tributh and Lagaly [21]. After purification, samples were $\mathrm{Na}^{+}$-saturated, and the remaining salt was removed by dialysis. The separation of $<0.2 \mu \mathrm{m}$ fraction was obtained by centrifugation and was applied in order to remove most of impurities, such as quartz [22]. The raw and purified samples were analyzed by XRD. The measurements were performed on an URD 6 instrument using CoKa radiation in $5^{\circ}$ to $80^{\circ} 2 \theta$ range, $0.03^{\circ}$ step, and 3 to $5 \mathrm{~s} / \mathrm{step}$ counting time. An example of one sample before and after purification is 
shown in Figure 4. The intensity of reflections of smectite was enhanced significantly after purification. The chemical composition of samples was determined by the X-ray fluorescence analysis (XRF) (Table 2). The measurement was performed on a MagiXPRO XRF-spectrometer. The chemical formula was calculated using the method described by Köster based on one formula unit (FU) $\left[\mathrm{O}_{10}(\mathrm{OH})_{2}\right]$ [23]. The layer charge density (LCD) was determined by the alkylammonium method (AAM) [24,25]. The results of chemical formula and the LCD of samples are listed in the studies of Wang et al. [26] and Wang and Liao [27]. The structural information such as octahedral cation content and the LCD obtained by these methods were used to investigate the relationships among the proportions of $c v$ and $t v$ layers, the cation distribution in octahedral sheet, and the LCD. All the experiments were performed on $<0.2 \mu \mathrm{m}$ fraction. The experimental data of sample characterization originate from studies of Wang et al. [26] and Wang and Liao [27].

Table 1. Origin of samples.

\begin{tabular}{cccc}
\hline Samples & Description & Source & Supplier \\
\hline XL_01_B8 & Montmorillonite & Wyoming, USA & Bundesanstalt für \\
XL_02_B9 & Montmorillonite & Wyoming, USA & Geowissenschaften und \\
XL_04_B14 & Beidellite & Hungary & Rohstoffe (BGR) \\
XL_06_B22 & Montmorillonite & Hungary & \\
\hline XL_09_SWy1 & Montmorillonite & Wyoming, USA & Society's Source Clays \\
XL_10_STx1 & Montmorillonite & Texas, USA & Repository, \\
XL_11_NAu1 & Nontronite & South Australia & Clay Minerals Society \\
XL_12_NAu2 & Nontronite & South Australia & (CMS) \\
\hline XL_13_14TR03 & Montmorillonite & Unidentified & \\
XL_14_41ValC18 & Beidellite & Valdagno, Italy & Karlsruhe Institute of \\
XL_16_4JUP & Montmorillonite & Argentina & Technology (KIT) \\
XL_17_2LP & Montmorillonite & Argentina & \\
XL_18_Valdol & Beidellite & Valdagno, Italy & \\
XL_19_NWa & Nontronite & Washington, USA & \\
\hline
\end{tabular}

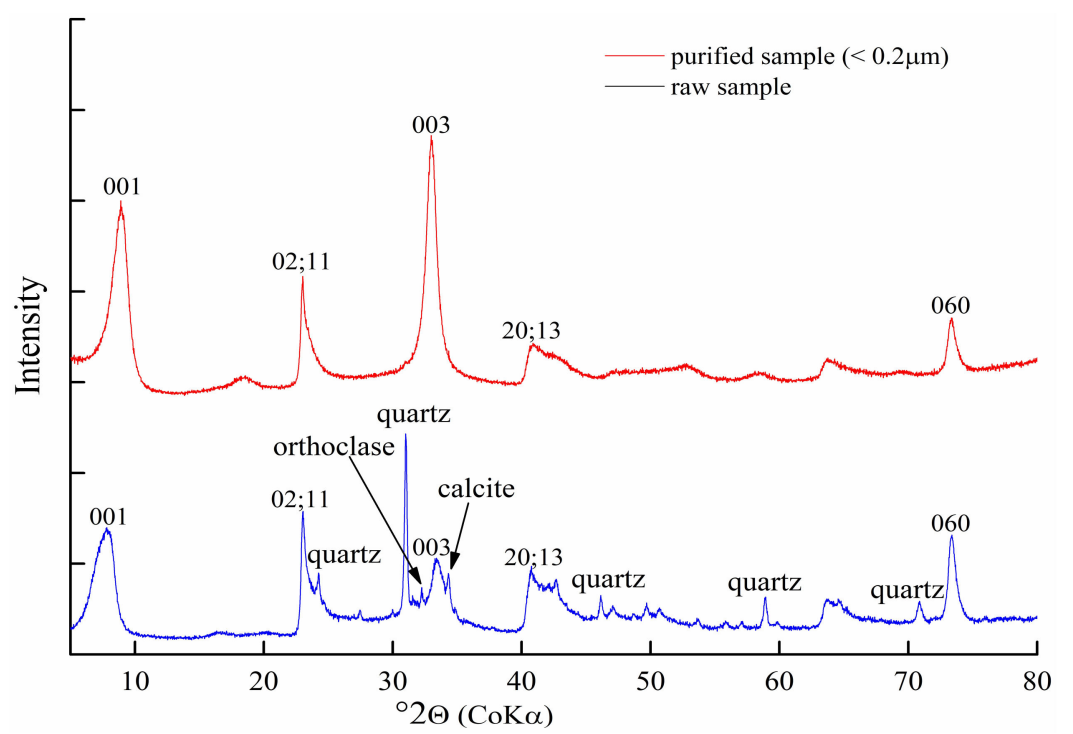

Figure 4. X-ray powder diffraction (XRD) patterns of Sample XL_09_SWy1 before and after purification. 
Table 2. Chemical compositions of samples measured by XRF analysis $(<0.2 \mu \mathrm{m}$ fraction).

\begin{tabular}{|c|c|c|c|c|c|c|c|c|c|c|c|c|c|c|c|}
\hline \multirow{2}{*}{ Samples } & \multicolumn{15}{|c|}{ Oxides (\%) } \\
\hline & $\mathrm{SiO}_{2}$ & $\mathrm{Al}_{2} \mathrm{O}_{3}$ & $\mathrm{Fe}_{2} \mathrm{O}_{3}$ & $\mathrm{MnO}$ & $\mathrm{MgO}$ & $\mathrm{CaO}$ & $\mathrm{K}_{2} \mathrm{O}$ & $\mathrm{NaO}$ & $\mathrm{TiO}_{2}$ & $\mathrm{CuO}$ & $\mathrm{P}_{2} \mathrm{O}_{5}$ & $\mathrm{Cr}_{2} \mathrm{O}_{3}$ & $\mathrm{NiO}$ & LOI * & Sum \\
\hline XL_01_B8 & 55.18 & 19.98 & 4.40 & 0.01 & 1.74 & 0.05 & 0.03 & 0.00 & 0.14 & 3.42 & 0.00 & 0.00 & 0.00 & 15.05 & 100.01 \\
\hline XL_02_B9 & 60.25 & 17.03 & 3.74 & 0.01 & 2.19 & 0.03 & 0.03 & 0.00 & 0.12 & 2.86 & 0.01 & 0.00 & 0.00 & 13.74 & 100.00 \\
\hline XL_04_B14 & 46.63 & 18.17 & 11.10 & 0.02 & 1.95 & 0.04 & 0.50 & 0.00 & 2.24 & 3.01 & 0.12 & 0.03 & 0.02 & 16.16 & 100.00 \\
\hline XL_06_B22 & 59.93 & 16.24 & 1.22 & 0.00 & 3.53 & 0.03 & 0.04 & 0.00 & 0.15 & 3.79 & 0.00 & 0.00 & 0.00 & 15.07 & 100.00 \\
\hline XL_09_SWy1 & 55.19 & 19.78 & 4.19 & 0.01 & 2.66 & 0.03 & 0.03 & 0.00 & 0.10 & 3.12 & 0.00 & 0.00 & 0.00 & 14.89 & 100.00 \\
\hline XL_10_STx1 & 58.03 & 18.10 & 2.00 & 0.01 & 2.93 & 0.04 & 0.06 & 0.00 & 0.27 & 3.16 & 0.02 & 0.00 & 0.00 & 15.37 & 100.00 \\
\hline XL_11_NAu1 & 43.63 & 7.36 & 30.25 & 0.01 & 0.00 & 0.03 & 0.01 & 0.00 & 0.03 & 3.82 & 0.00 & 0.01 & 0.01 & 14.85 & 100.00 \\
\hline XL_12_NAu2 & 48.35 & 2.49 & 32.67 & 0.00 & 0.01 & 0.04 & 0.02 & 0.00 & 0.04 & 3.07 & 0.00 & 0.00 & 0.01 & 13.30 & 100.00 \\
\hline XL_13_14TR03 & 55.14 & 16.60 & 1.76 & 0.01 & 4.98 & 0.03 & 0.02 & 0.00 & 0.09 & 4.09 & 0.00 & 0.00 & 0.00 & 17.27 & 100.00 \\
\hline XL_14_41ValC18 & 52.29 & 16.06 & 8.40 & 0.01 & 3.65 & 0.03 & 0.98 & 0.00 & 0.29 & 3.18 & 0.04 & 0.04 & 0.03 & 15.00 & 100.00 \\
\hline XL_16_4JUP & 52.29 & 18.24 & 7.44 & 0.03 & 2.13 & 0.04 & 0.32 & 0.00 & 0.93 & 3.11 & 0.03 & 0.00 & 0.00 & 15.45 & 100.00 \\
\hline XL_17_2LP & 54.20 & 18.62 & 4.48 & 0.02 & 3.00 & 0.03 & 0.06 & 0.00 & 0.15 & 2.99 & 0.00 & 0.00 & 0.00 & 16.44 & 100.00 \\
\hline XL_18_Valdol & 49.85 & 15.26 & 10.44 & 0.02 & 3.70 & 0.05 & 1.07 & 0.00 & 0.39 & 3.04 & 0.11 & 0.04 & 0.03 & 16.00 & 100.00 \\
\hline XL_19_NWa & 46.53 & 8.64 & 23.02 & 0.02 & 1.65 & 0.02 & 0.05 & 0.00 & 0.60 & 2.97 & 0.02 & 0.01 & 0.00 & 16.46 & 100.00 \\
\hline
\end{tabular}

${ }^{*}$ LOI: loss on ignition. 


\subsection{Thermal Analysis}

The thermogravimetric (TG) and differential thermal analysis (DTA) measurements were performed on the device SETARAM TGA 92-16.18. Before analysis, samples were stored in a desiccator over a saturated magnesium nitrate solution $\mathrm{Mg}\left(\mathrm{NO}_{3}\right)_{2}(53 \% \mathrm{RH})$ for at least $24 \mathrm{~h}$ to create a constant humidity condition. Then, a $30 \mathrm{mg}$ sample was used for each measurement, with a heating rate of $10^{\circ} \mathrm{C} / \mathrm{min}$ in the temperature range of 25 to $1000{ }^{\circ} \mathrm{C}$. The proportions of cis- and trans-vacant configurations were calculated by fitting the derivative thermogravimetry (DTG) curves in the range of 300 to $900{ }^{\circ} \mathrm{C}$ using the PeakFit program v4.12 (2007, Systat Software Inc., San Jose, CA, USA). According to Drits et al. [8], the areas of DTG peaks with the temperature below and above $600{ }^{\circ} \mathrm{C}$ correspond to the amount of trans- and cis-vacant configurations, respectively, in dioctahedral smectites. Each sample was fitted until the coefficient of determination $R^{2}$ was $>0.999$. The classification of $c v$ and $t v$ varieties was based on Wolters and Emmerich [28] (Table 3).

Table 3. Classification of dioctahedral smectites according to the thermal reaction (according to Wolters and Emmerich [28]).

\begin{tabular}{ccccc}
\hline Varieties & $c v$ & $c v / t v$ & $t v / c v$ & $t v$ \\
\hline $\begin{array}{c}\text { the area of dehydroxylation } \\
\text { peaks above } 600^{\circ} \mathrm{C} / \%\end{array}$ & $100-75$ & $74-50$ & $49-25$ & $24-0$ \\
\hline
\end{tabular}

\section{Results and Discussion}

\subsection{Characterization and Classification of Octahedral Structure}

Figure 5 shows the thermal behavior of samples with mainly $c v$ and $t v$ configurations. The dehydration of both samples was at around $120^{\circ} \mathrm{C}$. The dehydroxylation temperature of the samples with mainly $c v$ structure was around $700{ }^{\circ} \mathrm{C}$ and the sample with mainly tv structure was around $500{ }^{\circ} \mathrm{C}$, which agreed well with previous studies $[7,8,28,29]$.

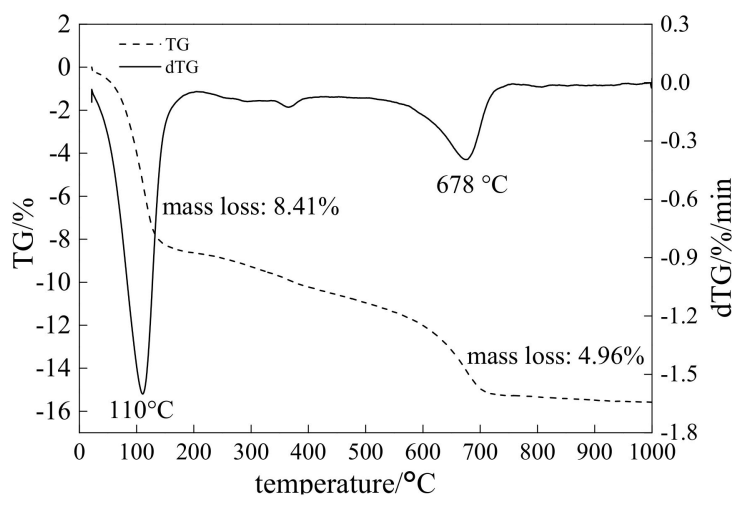

(a)

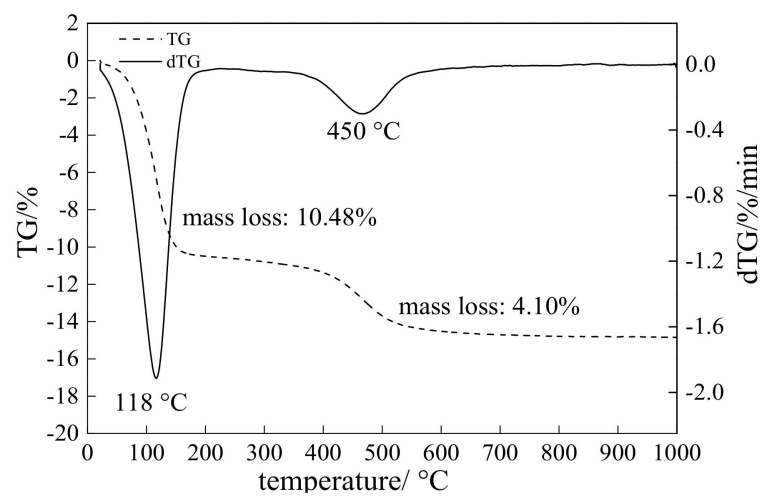

(b)

Figure 5. Thermal analysis of (a) sample XL_01_B8 with mainly cv structure; (b) Sample XL_12_NAu2 with to structure.

The results of the classification are presented in Table 4 . Fourteen samples covered a wide range of cis- and trans-vacant varieties and the mixtures of them, i.e., $c v, c v / t v, t v / c v$ and $t v$ (Table 4 ). Five samples were considered to be $c v$ varieties with a small amount of $t v$ configurations (Table 4). Samples XL_06_B22,XL_09_SWy1, and XL_17_2LP showed a similar peak profile with that of sample XL_01_B8, as shown in Figure 6a, and they showed a main peak near $700{ }^{\circ} \mathrm{C}$. Additionally, sample XL_10_STx1 had a small broad peak around $500^{\circ} \mathrm{C}$, which indicated a small amount of $t v$ (Figure $6 \mathrm{~b}$ ). 
Table 4. The cations content and the proportions of trans- $\left(\mathrm{W}_{t v}\right)$ and cis-vacant $\left(\mathrm{W}_{c v}\right)$ configurations of samples and the classification.

\begin{tabular}{|c|c|c|c|c|c|c|c|}
\hline \multirow{2}{*}{ Sample } & \multirow{2}{*}{$\begin{array}{c}\text { Tetrahedral Cation } \\
(\mathrm{mol} / \mathrm{FU})\end{array}$} & \multicolumn{3}{|c|}{ Octahedral Cations (mol/FU) } & \multicolumn{2}{|c|}{ Octahedral Sheet } & \multirow{2}{*}{ Classification } \\
\hline & & $\mathrm{Al}^{3+}$ & $\mathrm{Fe}^{3+}$ & $\mathrm{Mg}^{3+}$ & $\mathrm{W}_{c v}(\%)$ & $\mathrm{W}_{t v}(\%)$ & \\
\hline XL_01_B8 & 0.12 & 1.58 & 0.24 & 0.19 & 82.5 & 17.5 & \multirow{5}{*}{$c v$} \\
\hline XL_06_B22 & 0.09 & 1.53 & 0.08 & 0.45 & 90.0 & 10.0 & \\
\hline XL_09_SWy1 & 0.12 & 1.53 & 0.22 & 0.28 & 87.7 & 12.3 & \\
\hline XL_10_STx1 & 0.00 & 1.57 & 0.11 & 0.32 & 92.8 & 7.2 & \\
\hline XL_17_2LP & 0.10 & 1.48 & 0.24 & 0.32 & 95.7 & 4.3 & \\
\hline XL_02_B9 & 0.41 & 1.55 & 0.27 & 0.32 & 57.0 & 43.0 & \multirow{2}{*}{$c v / t v$} \\
\hline XL_13_14TR03 & 0.00 & 1.42 & 0.10 & 0.54 & 51.1 & 48.9 & \\
\hline XL_16_4JUP & 0.20 & 1.40 & 0.41 & 0.24 & 47.6 & 52.4 & $t v / c v$ \\
\hline XL_04_B14 & 0.44 & 1.23 & 0.65 & 0.23 & 1.3 & 98.7 & \multirow{6}{*}{ tv } \\
\hline XL_11_NAu1 & 0.49 & 0.21 & 1.83 & 0.00 & 0.0 & 100.0 & \\
\hline XL_12_NAu2 & 0.19 & 0.04 & 1.94 & 0.00 & 0.0 & 100.0 & \\
\hline XL_14_41ValC18 & 0.17 & 1.22 & 0.47 & 0.40 & 15.0 & 85.0 & \\
\hline XL_18_Valdol & 0.25 & 1.10 & 0.59 & 0.42 & 17.1 & 82.3 & \\
\hline XL_19_NWa & 0.42 & 0.43 & 1.46 & 0.21 & 0.8 & 99.2 & \\
\hline
\end{tabular}

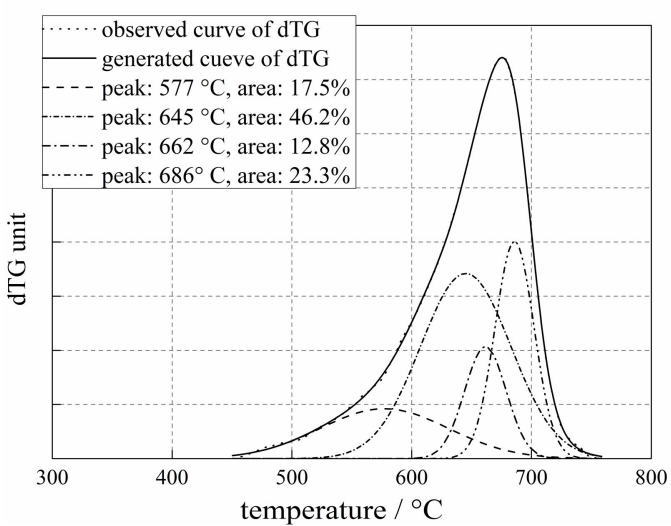

(a)

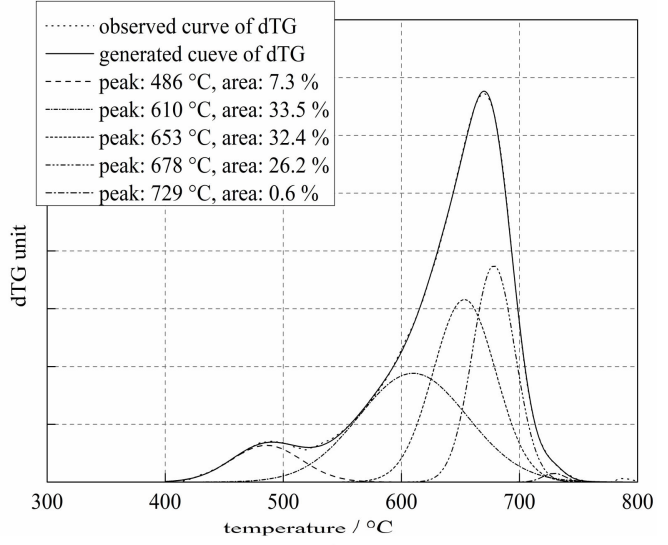

(b)

Figure 6. Examples of derivative thermogravimetry (DTG) curves of $c v$ smectites. (a) Sample XL_01_B8 with $82.5 \%$ of $c v$ layers; (b) Sample XL_10_STx1 with $92.8 \%$ of $c v$ layers.

Samples XL_02_B9 and XL_13_14TR03 can be classified as cv/tv varieties. They had a main peak above $600{ }^{\circ} \mathrm{C}$ which indicate one dehydroxylation reaction (Figure 7). Thus, the $c v$ configurations dominated in these two samples (Table 4).

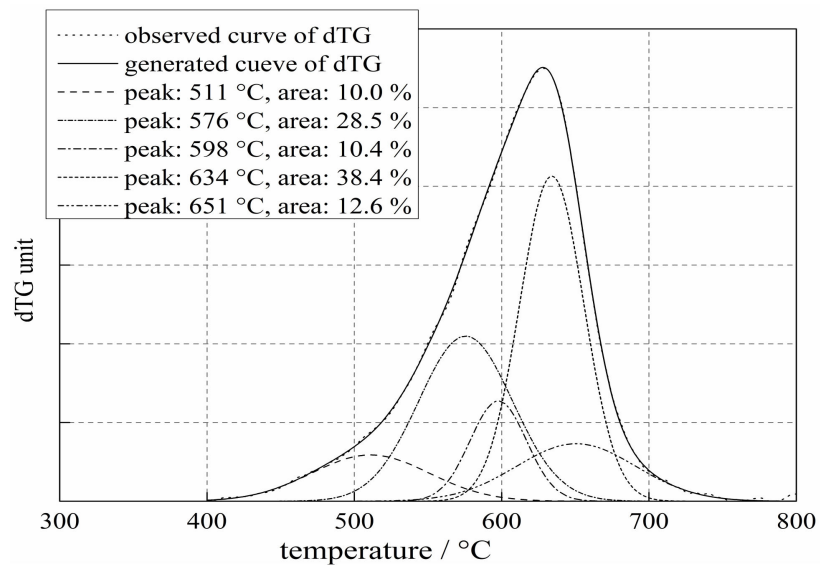

Figure 7. Examples of derivative thermogravimetry (DTG) curves of $c v / t v$ smectites. Sample XL_13_14TR03 with 51.1\% cv layers and $48.9 \%$ tv layers. 
Sample XL_16_4JUP was $t v / c v$ varieties. It contained two well resolved peaks in the $c v$ and $t v$ region which indicated two main dehydroxylation reactions, i.e., around $490^{\circ} \mathrm{C}$ and $650{ }^{\circ} \mathrm{C}$ (Figure 8 ). The sum of the peak area below $600{ }^{\circ} \mathrm{C}(52.4 \%)$ was larger than the area above $600{ }^{\circ} \mathrm{C}(47.6 \%)$, even though the peak at around $630^{\circ} \mathrm{C}$ was stronger than the peak at around $490{ }^{\circ} \mathrm{C}$. Therefore, the amount of $t v$ is larger than the amount of $c v$. Thus, the $t v$ configurations dominated in this sample.

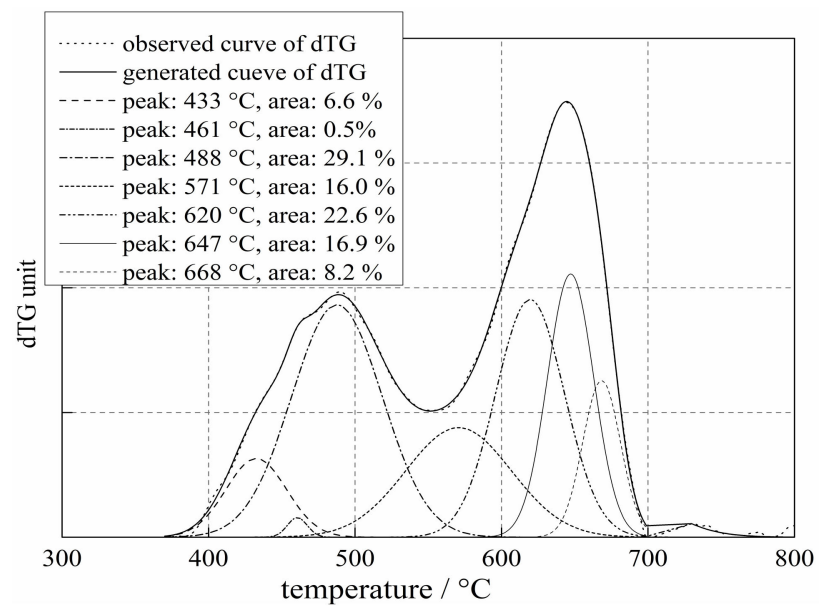

Figure 8. Examples of derivative thermogravimetry (DTG) curves of $t v / c v$ smectites. Sample XL_16_4JUP with $52.4 \%$ tv layers and $47.6 \% \mathrm{cv}$ layers.

Six samples were classified as tv varieties (Table 4), i.e., three nontronite samples XL_11_NAu1, XL_12_NAu2 and XL_19_NWa; three beidellite samples XL_04_B14,XL_18_Valdol and XL_14_41ValC18. Tsipursky and Drits [5] showed that montmorillonite and some Al-rich smectites are cis-vacant structure, beidellites and nontronites typically have a trans-vacant structure. As expected, nontronite samples XL_11_NAu1 and XL_12_NAu2 were found to be purely trans-vacant configurations, another nontronite sample XL_19_NWa contained 99.2\% tv structure. These three nontronites samples show similar dehydroxylation behavior to sample XL_04_B14; they had only one strong peak around $450{ }^{\circ} \mathrm{C}$ as shown in Figure 9a. It indicated one dehydroxylation reaction at this temperature. Two resolved peaks were also found in $t v$ samples XL_14_41ValC18 and XL_18_Valdol, that showed similar derivative thermogravimetry (DTG) curves with a DTG peak at around $500{ }^{\circ} \mathrm{C}$ than the peak at around $630{ }^{\circ} \mathrm{C}$ (Figure 9b).

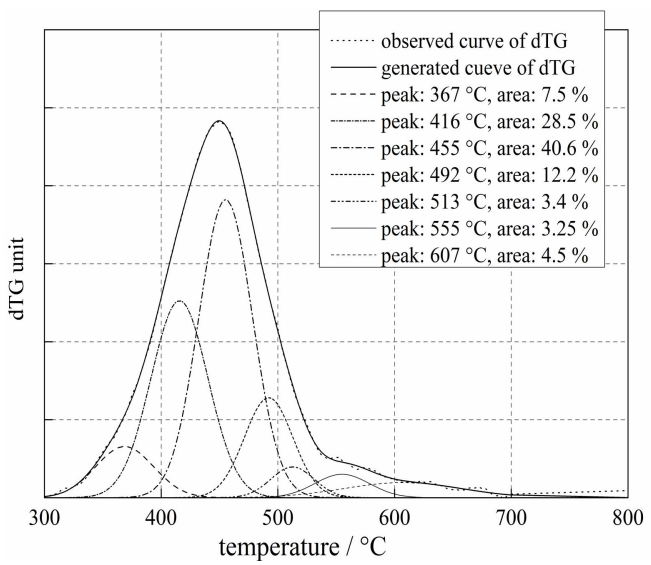

(a)

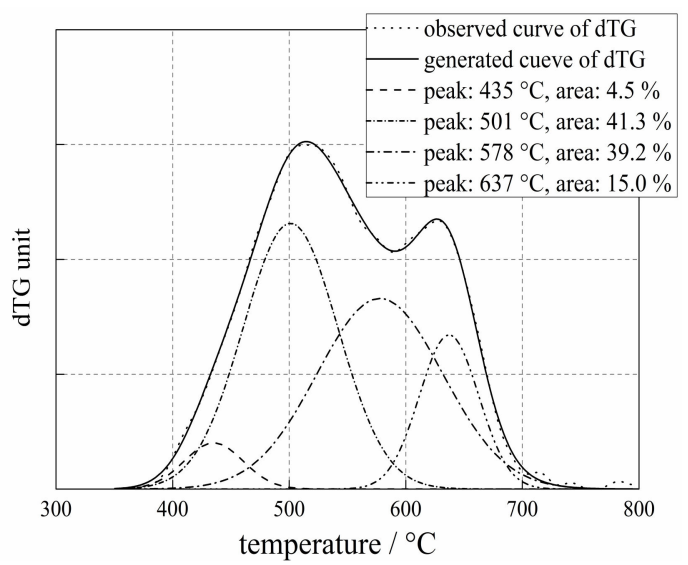

(b)

Figure 9. Examples of derivative thermogravimetry (DTG) curves of to smectites. (a) Sample XL_11_NAu1 with $100 \%$ of tv layers; (b) Sample XL_14_41ValC18 with $85 \%$ of tv layers. 
In summary, five samples were classified as the $c v$ variety with the main dehydroxylation reaction near $700{ }^{\circ} \mathrm{C}$ and six samples were classified as the tv variety with the main dehydroxylation reaction near $500{ }^{\circ} \mathrm{C}$. The remaining three samples contained two well resolved peaks corresponding to two main dehydroxylation reactions between 500 and $700{ }^{\circ} \mathrm{C}$. Two of these samples were considered to be the $c v / t v$ type; one of them was considered to be the $t v / c v$ type, and the ratio between the peak areas reflected the ratio between $c v$ and $t v$ layers. The results of the proportions of $c v$ and $t v$ configurations by thermal analysis agree with the expectations and confirm the classification of the selected samples.

\subsection{Relationship between Octahedral Cations and Octahedral Structure}

Drits et al. [16] considered that there was a compositional control on the distribution of octahedral cations over trans- and cis sites in dioctahedral smectites. Therefore, the relationships between the cation distribution in the octahedral sheet and the $c v, t v$ varieties were investigated. No relationship between the octahedral $\mathrm{Mg}^{2+}$ content and the proportion of $t v$ and $c v$ was detected (Figure 10). It indicated that the octahedral $\mathrm{Mg}^{2+}$ content is not correlated to the configuration of the octahedral sheets. In contrast, the influences of octahedral $\mathrm{Fe}^{3+}$ and $\mathrm{Al}^{3+}$ content on the structure of octahedral sheets is highly significant. A linear relationship was found between octahedral $\mathrm{Fe}^{3+}$ and $\mathrm{Al}^{3+}$ content and proportion of $c v$ and $t v$ configurations (Figure 11). The proportion of $t v$ structure was increased with increasing octahedral $\mathrm{Fe}^{3+}$ content and decreasing octahedral $\mathrm{Al}^{3+}$ content. It indicates that the substitution of $\mathrm{Al}^{3+}$ by $\mathrm{Fe}^{3+}$ in octahedral sheet could be the main reason for the formation of $t v$ varieties. Wolters and Emmerich [28] concluded that iron content controls the octahedral structure which is consistent with our study. Samples can be classified as tv varieties when octahedral $\mathrm{Fe}^{3+}>0.46 \mathrm{~mol} / \mathrm{FU}$, and pure tv varieties were found when octahedral $\mathrm{Fe}^{3+}>1.8 \mathrm{~mol} / \mathrm{FU}$ (Table 4 , nontronite samples XL_11_NAu1 and XL_12_Nau2). These two nontronites were found with a main dehydroxylation peak in the region around $450{ }^{\circ} \mathrm{C}$ (Figures $5 \mathrm{~b}$ and 9a). It is worth noting that the iron content affects the thermal stability of clay minerals; high iron content can reduce the dehydroxylation temperature due to the differences in bonding energy in the order $\mathrm{Mg}-\mathrm{OH}>\mathrm{Al}-\mathrm{OH}>\mathrm{Fe}-\mathrm{OH}[17,30]$. This can be one of the reasons that nontronites show a lower dehydroxylation temperature and tv configuration.

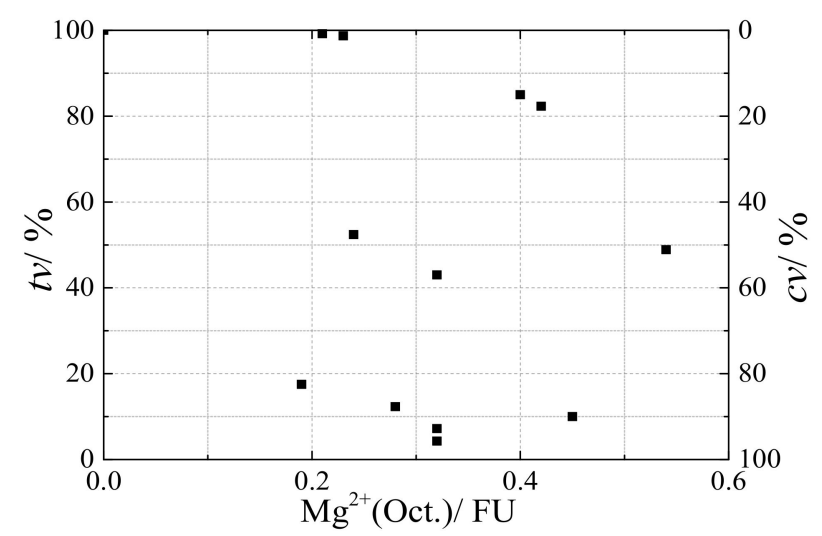

Figure 10. Relationship of the proportion of $t v$ and $c v$ layers to octahedral $\mathrm{Mg}^{2+}$ content. 


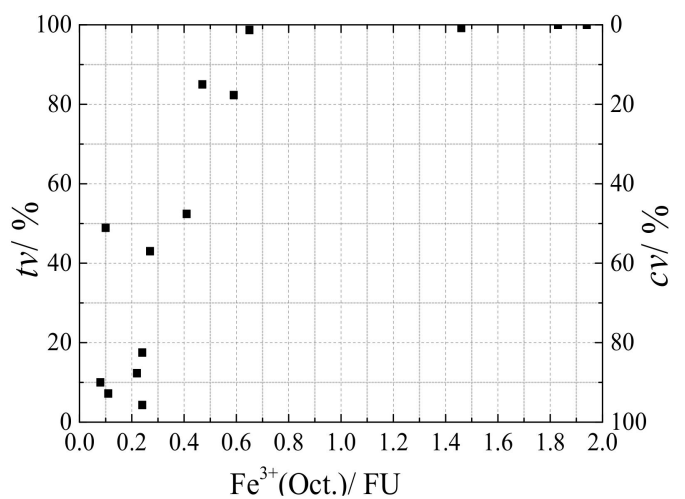

(a)

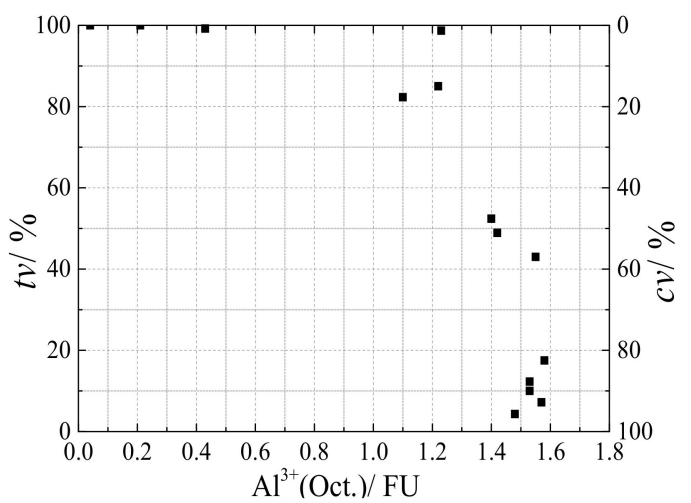

(b)

Figure 11. Relationship of the proportion of $t v$ and $c v$ layers to (a) octahedral $\mathrm{Fe}^{3+}$ content and (b) octahedral $\mathrm{Al}^{3+}$ content.

\subsection{Relationship between Layer Charge Density and Octahedral Structure}

The present results show that there is no relation between the proportion $t v$ and $c v$ configurations to the total layer charge density (Figure 12a). However, the relationship between the proportion of tv configuration to tetrahedral charge is more significant (Figure 12b). Wolters et al. [17] found a positive correlation between tetrahedral charge and the proportion of $t v$ configuration which is consistent with our results.

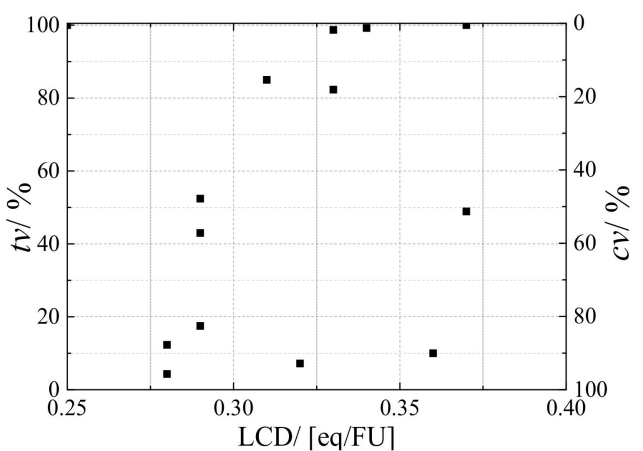

(a)

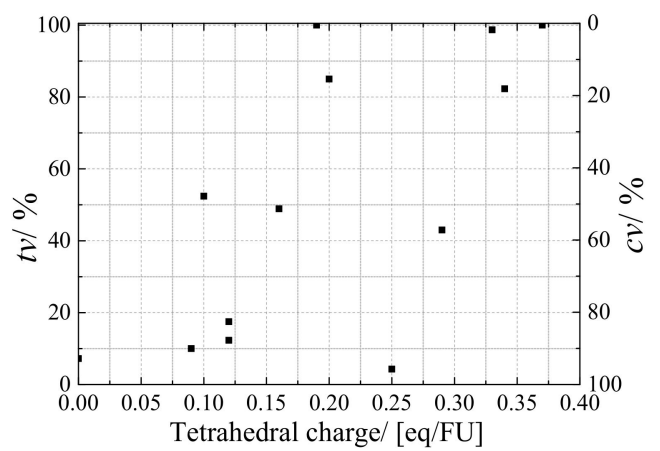

(b)

Figure 12. Relationship of the proportion of $t v$ and $c v$ layers to (a) layer charge density (LCD) and (b) tetrahedral charge.

Furthermore, the content of tetrahedral $\mathrm{Al}^{3+}$ is positively correlated with octahedral $\mathrm{Fe}^{3+}$ content, i.e., the content of tetrahedral $\mathrm{Al}^{3+}$ increases with the octahedral $\mathrm{Fe}^{3+}$ increasing (Figure 13). Cuadros [31] concluded that this could be because the tetrahedral $b$ dimension is bigger than the octahedral $b$ dimension. He concluded that an increase in octahedral $\mathrm{Mg}^{2+}+\mathrm{Fe}^{3+}$ causes an increase in tetrahedral $\mathrm{Al}^{3+}$ when correlating the ideal $b$ dimension of octahedral and tetrahedral sheets. Cuadros [31] pointed out that the octahedral sheet with $c v$ structure has a smaller $b$ dimension than the tv structure. Therefore, when the tetrahedral sheets have a low substitution (low tetrahedral charge), the sample tends to prefer the $c v$ structure; otherwise, it tends to be the tv structure. Kaufhold et al. confirmed that the existence of a positive correlation between iron content and tetrahedral charge from an energy point of view [18]. The authors concluded that the ratio of $t v$ and $c v$ depends on the iron content which is due to the octahedral iron or tetrahedral Al substitutions [18]. It can be concluded that the iron content is a dominant factor in the positive correlation between the proportion of $t v$, $c v$ configurations, and the tetrahedral charge. The high iron content is another factor for the lower dehydroxylation temperature of $t v$ configuration than $c v$ configuration. 


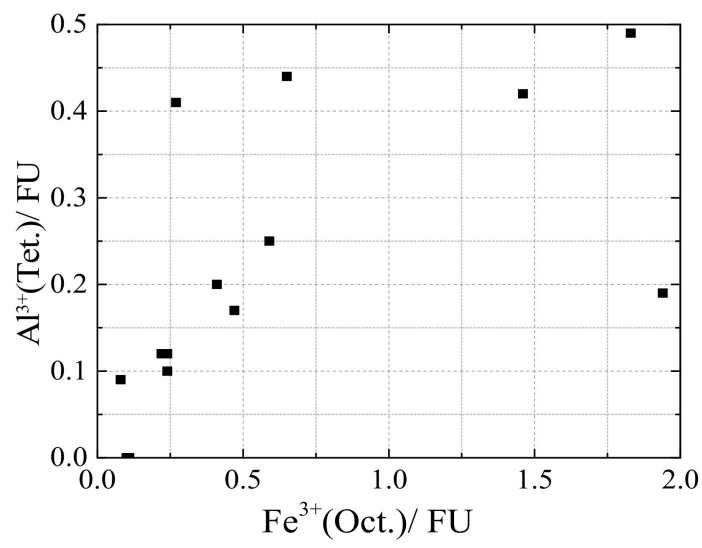

Figure 13. Relationship between tetrahedral $\mathrm{Al}^{3+}$ content and octahedral $\mathrm{Fe}^{3+}$ content.

\section{Conclusions}

As expected, the dehydroxylation temperature of samples with mainly $c v$ configuration is about $680^{\circ} \mathrm{C}$ and for samples with mainly tv configuration it is around $500^{\circ} \mathrm{C}$. The proportions of $c v$ and $t v$ can be determined by fitting the derivative thermogravimetry (DTG) curves. On the one hand, samples which were classified as the $c v$ variety showed a main dehydroxylation peak near $680^{\circ} \mathrm{C}$. On the other hand, samples which were classified as the tv variety showed a main dehydroxylation peak between 450 and $500{ }^{\circ} \mathrm{C}$. Samples of $c v / t v$ and $t v / c v$ varieties presented one main peak with a broad shoulder in their own region or two well resolved peaks in the $c v$ and $t v$ region which indicated two main dehydroxylation reactions. The content of $c v$ and $t v$ configurations is dependent on the chemical composition. The octahedral $\mathrm{Fe}^{3+}$ and $\mathrm{Al}^{3+}$ contents were highly related to the proportion of transand cis-vacant structures. With an increasing amount of octahedral $\mathrm{Fe}^{3+}$ and a decreasing amount of octahedral $\mathrm{Al}^{3+}$, the proportions of the $t v$ increased. Pure $t v$ dioctahedral smectites were formed when $\mathrm{Fe}^{3+}>1.8 \mathrm{~mol} / \mathrm{FU}$. No pure $c v$ configuration was found in these samples. No relationships among the total layer charge, octahedral $\mathrm{Mg}^{2+}$ content, and the proportion $t v$ and $c v$ were detected. A positive correlation between the tetrahedral charge and trans-vacancies was found and the octahedral iron content influences the tetrahedral charge. The present results indicate that the iron content has a significant effect on the structure of the octahedral sheet.

Author Contributions: Conceptualization H.W. and X.W.; data curation X.W.; formal analysis Y.L. and X.W.; writing-initial drafts X.W.; writing - review and editing Y.L., H.W., and X.W. All authors have read and agree to the published version of the manuscript.

Funding: This work was supported by the China Postdoctoral Science Foundation funded project (no. 2019M650320).

Acknowledgments: The authors greatly appreciate Reinhard Kleeberg (TU Bergakademie Freiberg) for his support in the laboratory and valuable comments which improved the manuscript. The authors thank Katja Emmerich and Annett Steudel (Karlsruhe Institute of Technology, KIT) for the assistance in the fitting of DTG curves by the PeakFit program. The authors would like to thank Gerhard Heide (TU Bergakademie Freiberg) for all the support during this work.

Conflicts of Interest: The authors declare no conflict of interest.

\section{References}

1. Murray, H.H. Bentonite Applications. In Applied Clay Mineralogy: Ocurrences, Processing and Application of Kaolins, Bentonites, Palygorskite-Sepiolite, and Common Clays, 1st ed.; Elsevier: Amsterdam, The Netherlands, 2007; Volume 2, pp. 111-130.

2. Brigatti, M.F.; Galan, E.; Theng, B.K.G. Structures and mineralogy of clay minerals. In Handbook of Clay Science, 1st ed.; Bergaya, F., Theng, B.K.G., Lagaly, G., Eds.; Elsevier: Amsterdam, The Netherlands, 2006; Volume 1, pp. 35-43.

3. Güven, N. Smectites. In Hydrous Phyllosilicates; Bailey, S., Ed.; Mineralogical Society of America: Washington, DC, USA, 1988; Volume 19, pp. 497-559. 
4. Méring, J.; Oberlin, A. The Smectites. In The Electron Optical Investigation of Clays; Gard, J.A., Ed.; Mineralogical Society: London, UK, 1971; Volume 3, pp. 193-229.

5. Tsipursky, S.I.; Drits, V.A. The distribution of octahedral cations in the 2:1 layers of dioctahedral smectites studied by oblique-texture electron diffraction. Clay Miner. 1984, 19, 177-193. [CrossRef]

6. Moore, D.M.; Reynolds, R.C., Jr. X-ray Diffraction and the Identification and Analysis of Clay Minerals, 2nd ed.; Oxford University Press: New York, NY, USA, 1997; pp. 335-339.

7. Drits, V.A.; Besson, G.; Muller, F. An improved model for structural transformations of heat-treated aluminous dioctahedral 2:1 layer silicates. Clays Clay Miner. 1995, 43, 718-731. [CrossRef]

8. Drits, V.A.; Lindgreen, H.; Salyn, A.L.; Ylagan, R.; McCarty, D.K. Semiquantitative determination of trans-vacantand cis-vacant 2:1 layers in illites and illite-smectites by thermal analysis and X-ray diffraction. Am. Mineral. 1998, 83, 1188-1198. [CrossRef]

9. Drits, V.A.; Sakharov, B.A.; Dainyak, L.G.; Salyn, A.L.; Lindgreen, H. Structural and chemical heterogeneity of illite-smectites from Upper Jurassic mudstones of East Greenland related to volcanic and weathered parent rocks. Am. Mineral. 2002, 87, 1590-1607. [CrossRef]

10. Drits, V.A.; Zviagina, B.B. Trans-vacant and cis-vacant 2:1 layer silicates: Structural features, identification, and occurrence. Clays Clay Miner. 2009, 57, 405-415. [CrossRef]

11. Muller, F.; Drits, V.A.; Plançon, A.; Besson, G. Dehydroxylation of $\mathrm{Fe}^{3+}$, $\mathrm{Mg}$-rich dioctahedral micas: (I) Structural transformation. Clay Miner. 2000, 35, 491-504. [CrossRef]

12. Muller, F.; Drits, V.A.; Tsipursky, S.I.; Plançon, A. Dehydroxylation of Fe ${ }^{3+}$, Mg-rich dioctahedral micas: (II) Cation migration. Clay Miner. 2000, 35, 505-514. [CrossRef]

13. Muller, F.; Drits, V.A.; Plançon, A.; Robert, J.L. Structural transformation of 2:1 dioctahedral layer silicates during dehydroxylation-rehydroxylation reactions. Clays Clay Miner. 2000, 48, 572-585. [CrossRef]

14. Dainyak, L.G.; Zviagna, B.B.; Rusakov, V.S.; Drits, V.A. Interpretation of the nontronite dehydroxylate Mössbauer spectrum using EFG calculations. Eur. J. Miner. 2006, 18, 753-764. [CrossRef]

15. Marchel, C.; Stanjek, H. Cation ordering in cis-and trans-vacant dioctahedral smectites and its implications for growth mechanisms. Clay Miner. 2012, 47, 105-115. [CrossRef]

16. Drits, V.A.; McCarty, D.K.; Zviagina, B.B. Crystalchemical factors responsible for the distribution of octahedral cations over trans- and cis-sites in dioctahedral 2:1 layer silicates. Clays Clay Miner. 2006, 54, 131-152. [CrossRef]

17. Wolters, F.; Lagaly, G.; Kahr, G.; Nüesch, R.; Emmerich, K. A comprehensive characterization of dioctahedral smectites. Clays Clay Miner. 2009, 57, 115-133. [CrossRef]

18. Kaufhold, S.; Kremleva, A.; Krüger, S.; Roesch, N.; Emmerich, K.; Dohrmann, R. Crystal-chemical composition of dicoctahedral smectites: An energy-based assessment of empirical relations. ACS Earth Space Chem. 2017, 1, 629-636. [CrossRef]

19. Davidovits, J. Geopolymers: Gerpolymers and geopolymeric materials. J. Therm. Anal. 1998, 35, 429-441. [CrossRef]

20. Ufer, K.; Stanjek, H.; Roth, G.; Kleeberg, R.; Dohrmann, R.; Kaufhold, S. Quantitative phase analysis of bentonites by the Rietveld method. Clays Clay Miner. 2008, 56, 272-282. [CrossRef]

21. Tributh, H.; Lagaly, G. Aufbereitung und Identifizierung von Boden- und Lagerstättentonen. I. Aufbereitung der Proben im Labor. GIT-Fachzeitschrift für das Laboratorium 1986, 30, 524-529.

22. Środoń, J. Indentification and quantitative analysis of clay minerals. In Handbook of Clay Science, 1st ed.; Bergaya, F., Theng, B.K.G., Lagaly, G., Eds.; Elsevier: Amsterdam, The Netherlands, 2006; Volume 1, pp. 765-776.

23. Köster, H.M. Die Berechnung kristallchemischer Strukturformeln von 2:1 Schichtsilikaten unter Berücksichtigung der gemessenen Zwischenschichtladungen und Kationenumtauschkapazitäten, sowie der Darstellung der Ladungsverteilung in der Strukturmittels Dreieckskoordinaten. Clay Miner. 1977, 12, 45-54. [CrossRef]

24. Lagaly, G.; Weiss, A. The layer charge of smectitic layer silicates. In Proceedings of the International Clay Conference, Mexico City, Mexico, 16-23 July 1975; pp. 157-172.

25. Laird, D.A.; Scott, A.D.; Fenton, T.E. Evaluation of the alkylammonium method of determining layer charge. Clays Clay Miner. 1989, 37, 41-46. [CrossRef]

26. Wang, X.L.; Kleeberg, R.; Ufer, K. Routine investigation of important structural parameters of dioctahedral smectites by the Rietveld method. Appl. Clay Sci. 2018, 163, 257-264. [CrossRef] 
27. Wang, X.L.; Liao, L.B. Rietveld structure refinement of Cu-trien exchanged nontronites. Front. Chem. 2018, 6, 558. [CrossRef]

28. Wolters, F.; Emmerich, K. Thermal reactions of smectites-Relation of dehydroxylation temperature to octahedral structure. Thermochim. Acta 2007, 462, 80-88. [CrossRef]

29. Emmerich, K.; Kahr, G. The cis- and trans-vacant variety of a montmorillonite: An attempt to create a model smectite. Appl. Clay Sci. 2001, 20, 119-127. [CrossRef]

30. Köster, H.M.; Schwertmann, U. Dreischichtminerale. In Tonminerale und Tone; Jasmund, K., Lagaly, G., Eds.; Steinkopff Verlag: Darmstadt, Germany, 1993; pp. 33-58.

31. Cuadros, J. Structural insights from the study of Csexchanged smectites submitted to wetting and drying cycles. Clay Miner. 2002, 37, 473-486. [CrossRef]

(C) 2020 by the authors. Licensee MDPI, Basel, Switzerland. This article is an open access article distributed under the terms and conditions of the Creative Commons Attribution (CC BY) license (http://creativecommons.org/licenses/by/4.0/). 